\title{
Healthy ageing in Germany - common care and insurance funding. Institutional and financial dimension of Health Promotion for Older People
}

\author{
Stanisława Golinowska ${ }^{1,2}$, Kai Huter ${ }^{3,4}$, Christoph Sowada ${ }^{1}$, \\ Milena Pavlova ${ }^{4}$, Agnieszka Sowa ${ }^{2}$, Heinz Rothgang ${ }^{3,5}$
}

\begin{abstract}
${ }^{1}$ Institute of Public Health, Faculty of Health Sciences, Jagiellonian University Medical College, Cracow, Poland; ${ }^{2}$ Institute of Labour and Social Studies, Warsaw, Poland; ${ }^{3}$ University of Bremen, SOCIUM - Research Center on Inequality and Social Policy, Germany; ${ }^{4}$ Department of Health Services Research; CAPHRI, Maastricht University Medical Center; Faculty of Health, Medicine and Life Sciences, Maastricht University, The Netherlands; ${ }^{5}$ High-profile area Health Sciences, University of Bremen, Germany
\end{abstract}

Address for correspondence: Stanisława Golinowska, Jagiellonian University Medical College, Grzegórzecka 20 St., 30-351 Cracow, Poland, stellag@onet.pl

\section{Abstract}

In Germany responsibilities for health promotion and prevention lies with a multitude of different actors and institutions. The institutional arrangement of health promotion is shaped by the German federal structure of the state on the one hand and by a health care system that is characterized by divided responsibilities between governmental organisations, self-administered bodies and non-governmental organisations on the other hand. Although federal-level programs are successfully implemented in the country, the attempt of the Federal government to consolidate and clarify responsibilities in the public health area meets resistance. The Preventive Health Care Act from 2015 is an attempt to strengthen health promotion, its effective impact will be for the future to show.

Health promotion activities are initiated and provided by a variety of institutions: governmental, self-administered and voluntary (NGOs) often based on networks form. They cover activities on federal, Länder and local level. The Federal Ministry of Health and federal health agencies (specially BZgA) play an important role in this field. They created a number of health promotion regulation and activities initiatives which added to disease and addiction prevention. In health promotion for older people (HP4OP) programs, there is also a number of regionally and locally oriented initiatives. In this paper, we outline main features of the HP4OP activities in Germany with regard to institutions and financing mechanism. In addition, we describe health-targeting programmes/projects indicated as good practices:(a) established and developed in Germany and (b) provided by the European Commission with significant participation of German institutions. The multitude and variety of HP4OP programs differentiate positively German health system from other health systems in ageing countries.

Key words: health promotion, older people, health insurance, Germany, funding and financing, institutions, good practices

\section{Introduction}

Germany is one of the conservative welfare states, which offer relatively generous benefits and social services, and provide these based on a social insurance financial mechanism. The legislative authority for most policy areas in Germany is divided between the federal level (Bund) and the 16 states (Länder). The legislative authority for the health field has developed over time, which has led to the current situation, where the authority is divided between governmental organisations, self-administered bodies, and non-governmental organisations, resulting in a multi-dimensional division of responsibilities between different organisations on the Federal, Länder and communal level. Although Federal-level programs (e.g. some screening and health prevention pro- 
grammes) are successfully implemented in the country, the attempt of the Federal government to consolidate and clarify responsibilities in the public health area has met resistance [1].

Health care is based on a social insurance principle and health promotion programmes are mainly financed by insurance contributions [2]. Nevertheless, there is a clear institutional separation between public health services, ambulatory care and hospital (inpatient) care.

Health promotion activities are initiated and provided by a variety of institutions, including the Federal Ministry of Health, Länder health ministries, local governments, self-administered bodies of health-care providers, especially the Statutory Health Insurance (SHI) and NGOs. Nevertheless the Federal Ministry of Health plays an important role and has recently initiated several legal reforms to strengthen prevention and health promotion and to include a focus on older people (HP4OP), e.g. by defining national health targets in this area. The German Forum for Prevention and Health Promotion was created in 2002 based on stakeholder initiatives at the federal level to define health targets and outline ways to strengthen prevention as well as to promote the development of broad preventive programmes and information, including prevention targeting older adults [1]. In the following years the ministry created a set of public health initiatives that added disease and addiction prevention. In health promotion for older people (HP4OP), there are more regionally and locally oriented initiatives.

In this paper, we first present some general data about health related demographic and epidemiological information (Section 2). We then provide an overview of the specific organisational structure of health issues in Germany (Section 3) and discuss the current legal and regulatory landscape relevant to health promotion and prevention generally and for older people particularly (Section 4). The remaining two sections contain information on the funding of organizations and activities involved in HP4OP (Section 5) and on selected programmes and activities in this area indicated as good practices (Section 6).

\section{Population ageiny and health status of the older population}

Germany has one of the world's most rapidly ageing populations. The share of the older people in Germany is significant accounting for $15.4 \%$ of the population for people aged $65-79$ and to $5.4 \%$ of the population for people being over 80 years old in 2014 . These indicators are above the EU-28 average of $13.4 \%$ for people aged 65-74 and 5.1\% for people aged 80 or more.

The average life expectancy at birth is 83.2 for women and 78.6 for men, which is close to the EU-28 average of 83.3 for women and 77.8 for men. The healthy life years at birth are estimated as 57.8 for men and 57.0 for women, which is below the EU-28 average of 61.4 years for men and 61.5 years for women. According to these estimates, men spend an average of $74 \%$ and women $69 \%$ of their lives in good health and without disability.
The average life expectancy of men aged 65 is 18.2 and women is 21.1 for women, which is slightly above the EU-28 level for men (17.9 years) and close to the average EU-28 level for women (21.3 years). Healthy life years at the age of 65 equal 7 for both men and women, which constitutes about $39 \%$ of the average life expectancy at this age for men and 33\% for women. This is below the EU-28 average of HLY (healthy life years) at the age of 65 , which is equal to 8.5 for men and 8.6 for women (see Table I).

\begin{tabular}{|l|}
\hline Life expectancy: \\
Life expectancy at birth males/females: $78.6 / 83.2$ years \\
Life expectancy at 65 males/females: $18.2 / 21.1$ years \\
\hline Healthy life years: \\
Healthy life years at birth males: 57.8 years \\
Healthy life years at birth females: 57.0 years \\
Healthy life years at 65 males: 7 years \\
Healthy life years at 65 females: 7 years \\
\hline Share of older population: \\
Proportion of population aged $65+: 20.8 \%$ of total population \\
Proportion of population aged $80+: 5.4 \%$ of total population \\
Old age dependency ratio $65+: 32.7 \%$ \\
\hline
\end{tabular}

Table I. Population ageing indicators - Germany (data for 2014/2015).

Source: Based on the Eurostat database, http://ec.europa.eu/ eurostat/data/database; accessed: 7.04.2016.

The proportion of older people (65+) in the population is projected to increase from $20.8 \%$ in 2014 to $32.3 \%$ in 2060 . The share of the oldest old $(80+)$ is projected to more than double: from $5.4 \%$ in 2014 to $13.4 \%$ in 2060 . Given these trends, the projected old age dependency ratio will increase from $32.7 \%$ in 2015 to $59.2 \%$ in 2060 (see Table I).

Mortality from all causes in the population aged $65+$ amounted to $4,528 / 100,000$ population in men and 3,134/100,000 population in women in 2013 (see Table II). The main cause of death in the older population are cardiovascular diseases constituting about $39 \%$ of deaths in men $(17,778 / 100,000$ population) and $43 \%$ of deaths in women $(1,358 / 100,000$ population) followed by cancers, which amount for $27 \%$ of deaths in men $(1,225 / 100,000$ population) and $23 \%$ in women (707/100,000 population). Pulmonary system diseases are the third most important cause of deaths amounting to $9 \%$ of deaths in men (404/100,000 population) and $7 \%$ in women $(216 / 100,000$ population).

Health status self-assessment worsens with age. At the age of $65-74$, about $41 \%$ of older people assess their health status as fair and only $10 \%$ reports bad or very bad health (EU-SILC data of 2014). In the population aged $75-84$, these shares increase to $50 \%$ and $15 \%$ respectively and above 85 years of age, they reach $56 \%$ and $29 \%$ (see Table II). The share of people with two or more chronic illnesses amounted to $76 \%$ of women and $68 \%$ of men aged $65-74$, and $82 \%$ of women and $74 \%$ of men above the age of 75 in 2009 [3]. The most com- 
Mortality rates (2013):

Mortality from all causes age $65+$ males: $4528 / 100000$ population

Mortality from all causes age $65+$ females: $3134 / 100000$ population

Self-assessed health status (2014):

Health status self-assessment age of $65-74$ fair/bad or very bad: $41 \% / 10 \%$

Health status self-assessment age of $75-84$ fair/bad or very bad: $50 \% / 15 \%$

Health status self-assessment age of $85+$ fair/bad or very bad: $56 \% / 29 \%$

Prevalence of two or more chronic illnesses (2009):

Share of people age of $65-74$ with two or more chronic illnesses males/females: $68 \% / 76 \%$

Share of people age of $75+$ with two or more chronic illnesses males/females: $74 \% / 82 \%$

Self-perceived long-standing limitations in usual activities due to health problems (2013):

Age group 65-74 males/females: 54\%/53\%

Age group 75-84 males/females: $64 \% / 70 \%$

Age group $85+$ males/females: $76 \% / 88 \%$

Table II. Health status of the older population - Germany.

Source: Based on the Eurostat databases; EU-SILC data of 2014, http://ec.europa.eu/eurostat/data/database; accessed: 7.04.2016 and Robert Koch Institut data [3].

mon chronic conditions in the older population include circulatory system diseases, cancers, muscles and skeleton illnesses and diabetes. The prevalence of circulatory system diseases accounts to $20.5 \%$ in women and $31 \%$ in men aged $65-74$, and $35.1 \%$ in women and $40 \%$ in men aged $75+$. The prevalence of cancers is reported as $17.5 \%$ in women and $13.6 \%$ in men aged $65-74$, and $16.6 \%$ in women and $18.8 \%$ in men aged $75+$.

A similar occurrence is observed for the diagnosis of diabetes: $16.3 \%$ in women and $18.2 \%$ in men aged 65-74, and almost $20 \%$ for men and women above 75 years of age. Illnesses of muscles and the skeleton (osteoporosis, arthritis, rheumatism) are very prevalent in the oldest population, reported by $63.7 \%$ of women and $45.8 \%$ of men aged $75+$.

Long-standing limitations in everyday activities caused by health problems were reported by $54 \%$ of men and $53 \%$ of women aged $65-74 ; 64 \%$ of men and $70 \%$ of women aged $75-84$; and $76 \%$ of men and $88 \%$ of women above the age of 85 in 2013 (see Table II).

The main risk factors for poor health in older age include smoking, excessive alcohol consumption and physical inactivity. $8.9 \%$ of women and $11.6 \%$ of men aged 65 to 74 smoke. $18 \%$ of women and $34 \%$ of men in this age group drink excessively. Studies of the Robert Koch Institute [3] show that $16.8 \%$ of women and $19.3 \%$ of men aged $60-69$, and $11 \%$ of women and $16.5 \%$ of men age $70+$ are regularly and intensively physically active. Obesity is a frequent risk factor with $22 \%$ of men and $24 \%$ of women aged $65-74$, and $19 \%$ of men and women age $75+$ reporting Body Mass Index equal or higher than 30. The incidence rate for fatal falls is reported as 74.2 per 100,000 population $65+$.

\section{Organisational solutions for health promotion and prevention in Germany}

The institutional arrangement of health promotion in Germany is shaped by the German federal structure of the state on the one hand and by a health care system that is characterized by divided responsibilities between governmental organisations, self-administered bodies and non-governmental organisations on the other hand. There are a multitude of different stakeholders, structures and interests involved. There are no standardised or uniform structures of health promotion [4].

The "Pro-Health 65+" project experts [5] indicated that the most important institutions for providing health promotion functions are regional/local actors. Health promotion on the regional level is under the authority of the Länder legal regulations - and in consequence regional activities and services - may differ widely. Many interventions or projects specifically for older people are initiated by local health insurances and non-governmental organisations. Local sports clubs and adult education centres provide many activities for older people as part of their general range of activities.

In general, health promotion activities may be initiated, shaped or influenced by a wide range of different actors including governmental institutions (1), the selfadministered institutions of the health sector (2) and non-governmental institutions (3) on different policy levels (Federal, Länder and local level). Deeper analysis stresses the importance of the national cooperation networks. Strong networks in health promotion are first of all: The National Health Targets, The Equity in Health and Healthy Cities Network. They coordinate activities and link actors across different levels and sectors.

To illustrate the complex and specific German institutional arrangement in health promotion and the multitude of institutions and organisations involved, Figures 1-3 present the main institutional actors in these three fields: governmental institutions (Figure 1), public and self-administered bodies (Figure 2) non-governmental (voluntary) organisations (Figure 3). However some of these institutions operate in more than one field, particularly those in the form of a network, such as the State Health Conferences and the Working Platforms on Health Promotion and Prevention. 


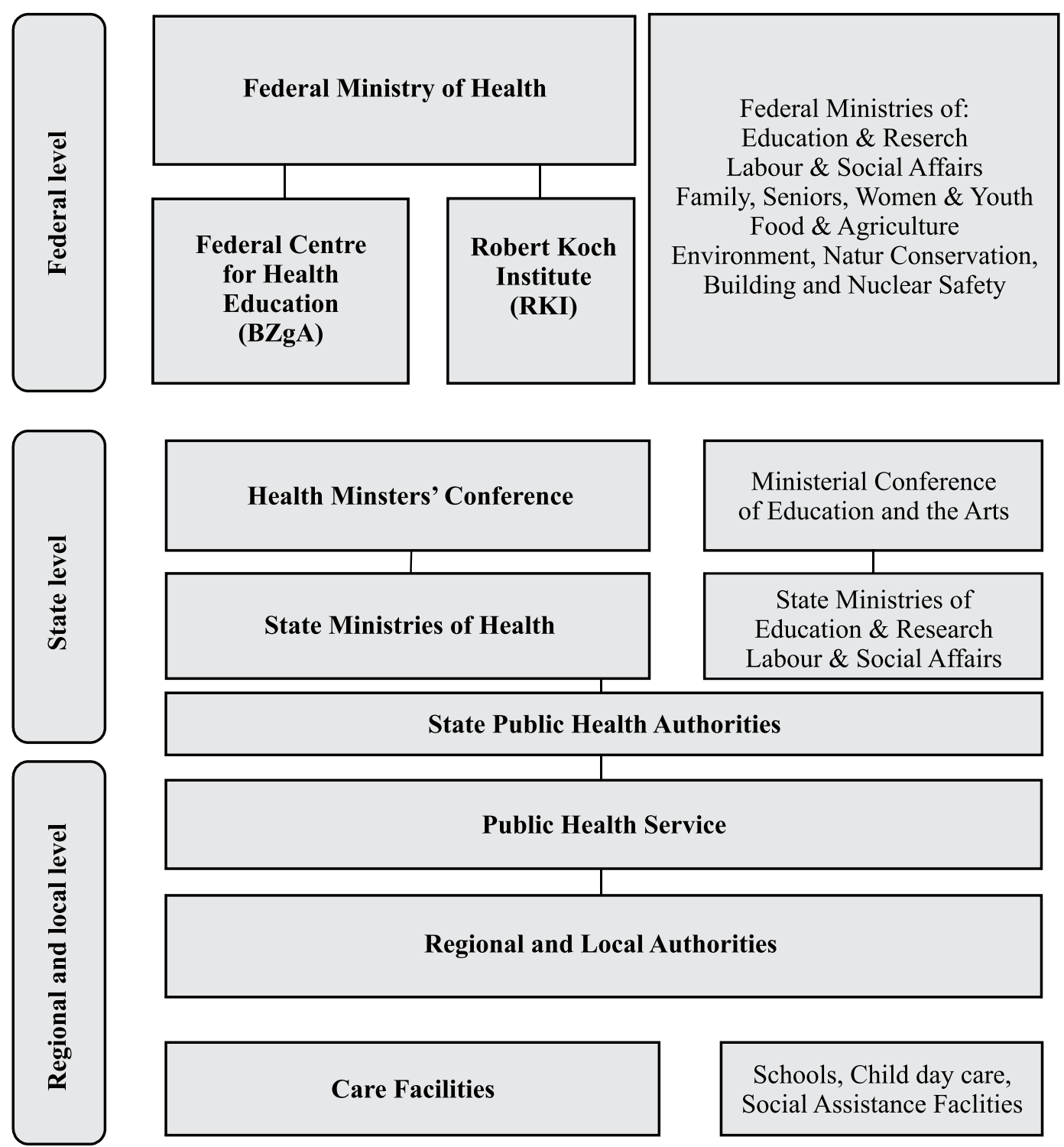

Figure 1. Governmental institutions involved in health promotion and prevention in Germany.

Sources: Inspired by Blümel S. [6] and Kunkel T. [7], http://www.chrodis.eu/wp-content/uploads/2015/02/Germany-country-review; accessed: 14.09.2016.

Health promotion on the federal level is a special field of the Federal Centre for Health Education (Bundeszentrale für gesundheitliche Aufklärung - BZgA). This institution was founded in 1967. Its main task is information and health education as well as the organisation and coordination of prevention campaigns, but it is also - and to an increasing extent - the responsible agency for many health promotion and prevention projects.

The Robert Koch Institute (RKI) is a traditional epidemiologic research institute responsible for tracking diseases (communicable and non-communicable) and assessing health status of both the entire population and its specific groups. The RKI systematic reports on the health situation and health care needs in Germany.
Health promotion as a part of the whole public health system is predominantly in the responsibility of the 16 Länder.

The Health Ministers' Conference plays a specific role in the governmental structure of the Länder. The Conference aims at coordinating activities of the Länder, is legal initiative and has a guiding role for health policies on the Länder-level. In 1991 the Health Minister's Conference released an influential resolution (GMKEntschließung) titled "Opportunities for preventive health care, disease prevention and health promotion in Germany". This resolution resulted in many state laws on health promotion in the Länder as a part of their public health services. 


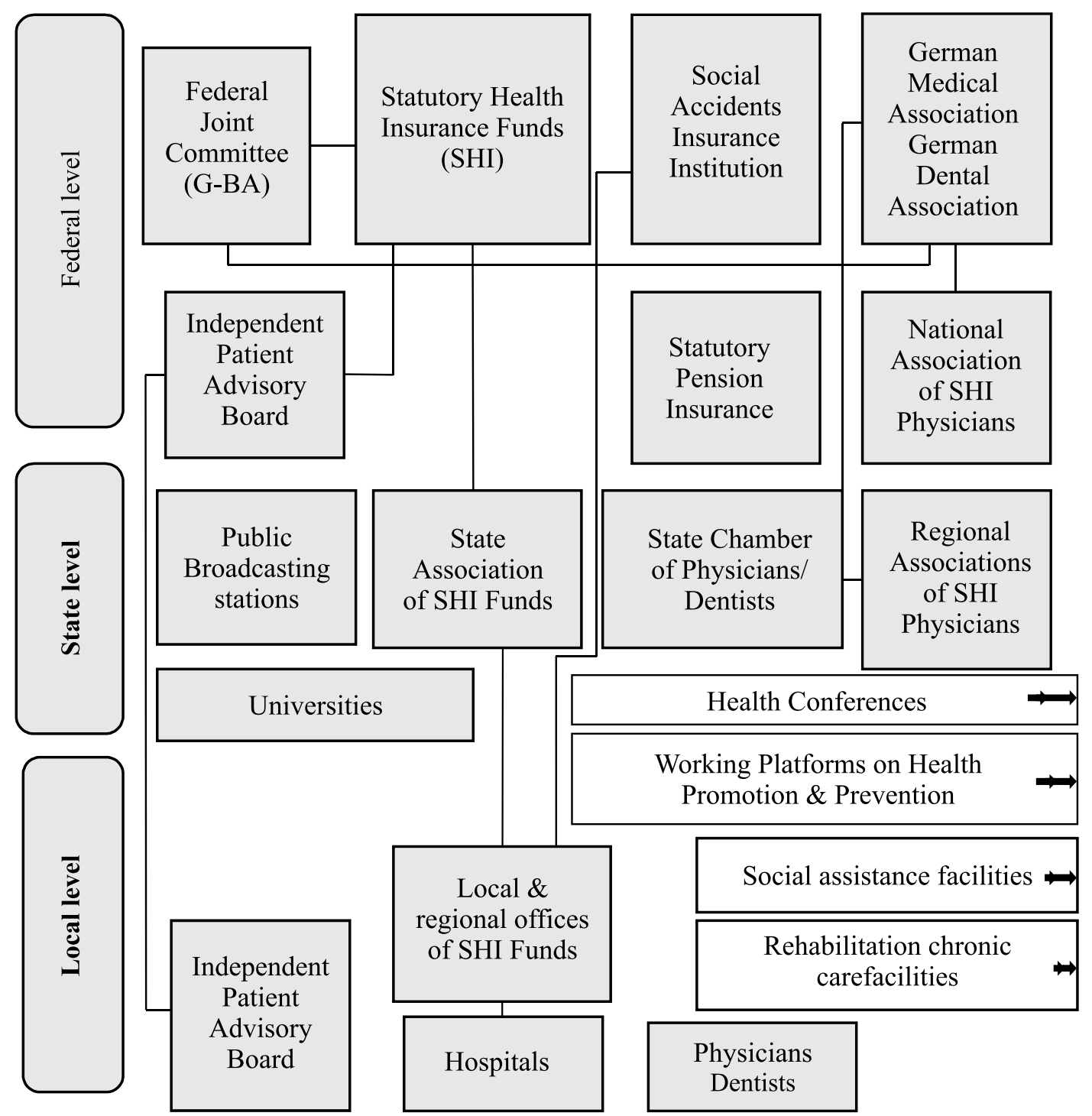

Figure 2. Public and self-administered bodies involved in health promotion and prevention.

Sources: Inspired by Blümel S. [6] and Kunkel T. [7], http://www.chrodis.eu/wp-content/uploads/2015/02/Germany-country-review; accessed: 14.09.2016.

Most of the Länder institutions have transferred authority for health promotion to local governments. Various health promotion programmes are locally initiated and performed with the involvement of NGOs, local health insurances, medical firms, individual doctors and nurses, local self-governments and social activists as well.

A specific feature of the administrative system of the German state is the self-administration of many public institutions. Health related institutions such as: insurance funds, medical chambers and various federal associations and boards are self-administrated. This creates a relatively complex picture of institutional order.

To overcome the fragmented responsibilities for health promotion and to strengthen the cooperation of different actors on the federal, Länder and local levels, several cooperation networks have been founded over the years. Some Länder initiated "Health Conferences" on state or regional levels to improve the coordination of health promotion initiatives [1]. The Forum on Prevention and Health Promotion (founded in 2002) merged in 2007 to form the Federal Association for Prevention and Health Promotion (Bundesvereinigung Prävention und Gesundheitsförderung e.V.). Its task is to strengthen prevention and health promotion in all political spheres, to define health targets and to establish sustainable organizational structures [1]. It comprises 130 organisations and is funded by the Ministry of Health. The Cooperation Network "Equity in Health" was founded in 2003 by the Federal Centre for Health Education (BZgA) together with the Länder to strengthen social situation based health promotion (see Section 5). Following the Ottawa-Charta of 1986, the Healthy Cities Network was founded in Germany in 1989. By now more than 150 


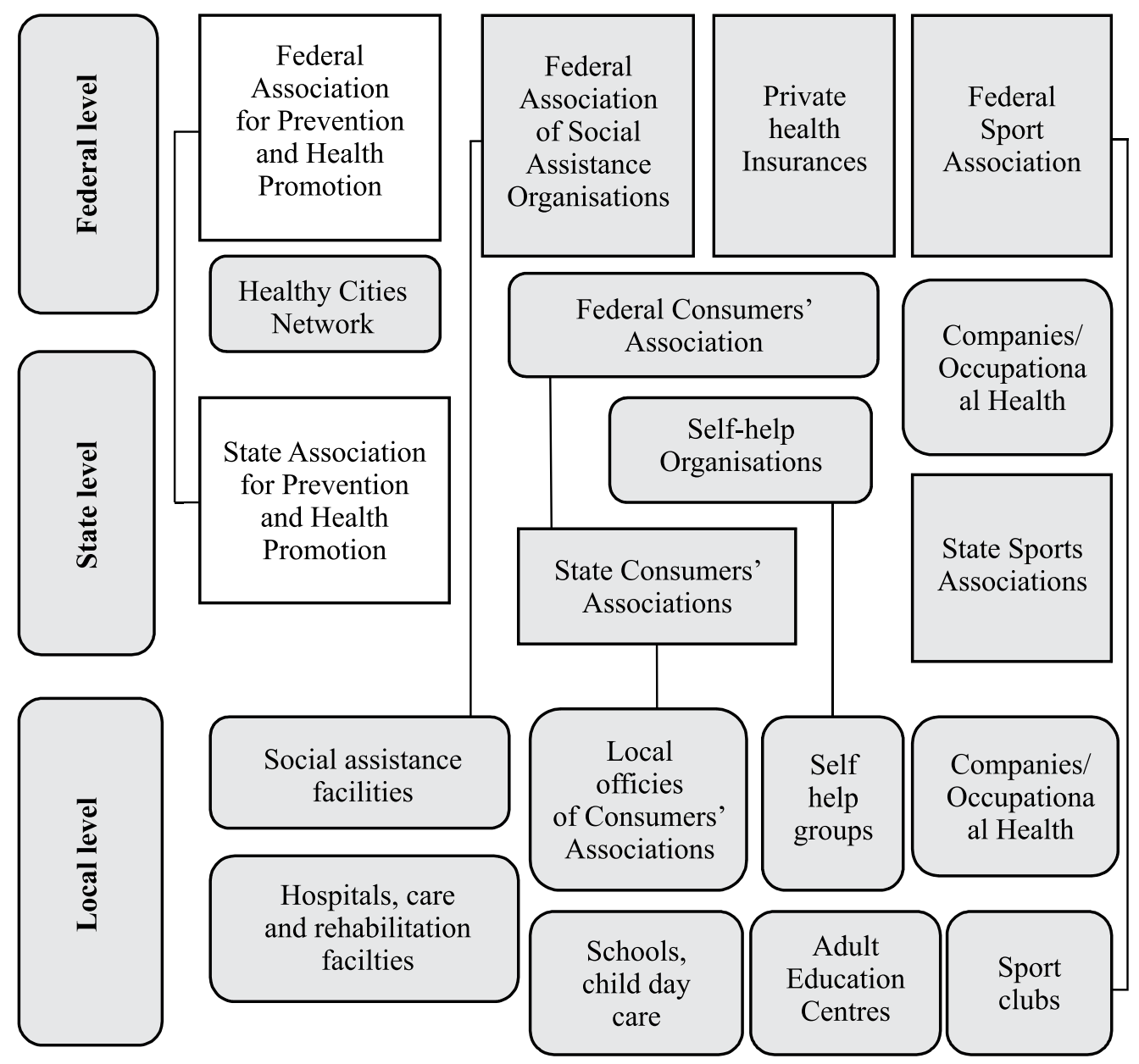

Figure 3. Non-Governmental Organisations involved in health promotion and prevention.

Sources: Inspired by Blümel S. [6] and Kunkel T. [7], http://www.chrodis.eu/wp-content/uploads/2015/02/Germany-country-review; accessed: 14.09.2016.

German cities are part of this network that is focussed on health promotion on the communal level encompassing different areas: health, traffic, urban planning, housing etc.

Locally operated NGOs in the field of health promotion in Germany very often have an umbrella organisation on the Länder and/or Federal levels. There well-known associations for health prevention and health promotion on both levels are presented in Figure 3. In the field of senior issues the BAGSO - Bundesarbeitsgemeinschaft der Senioren-Organisationen (German Association of Organisations for Seniors) is an important stakeholder as it is an umbrella organisation of more than 100 national associations that are concerned with the interests of older people and is involved in many projects and political initiatives on health promotion for older people.

An important NGO-actor on the federal level is the Association of Social Assistance Organisations, which plays an important advocacy role. A sign of the modern age is the network structure to unite similar health promotion activities from different settings, administrative levels and territorially places [8].
Generally, NGOs, in their modern form, are an important sector of organisations that play a double role: serving as advocacy/ lobby groups for HP4OP and providing healthy ageing activities for older people in various settings.

\section{Leyal basis for health promotion activities}

The main sphere of influence and regulation for the national health policy is social legislation, mainly with respect to the social insurances. Legal regulations concerning prevention and health promotion are included in different parts of the Social Code (SGB). Legal regulations apply to the sphere of employment seekers/employment promotion (SGB II\&III); the statutory health insurance (SGB V), the statutory retirement insurance (SGB VI), the statutory accident insurance with respect to safety and health promotion at work (SGB VII), the assistance for children and adolescents (SGB VIII) and the rehabilitation and participation of disabled people (SGB IX). SGB XI and SGB XII specifically target older people. SGB XI applies to social care and prescribes preven- 
tive interventions ( $\$ 5)$ and duties regarding information on health promotion (\$7) for the social care insurances. SGB XII regulates social assistance, prescribes an overall priority of prevention and rehabilitation over social assistance (\$14) and defines services promoting social inclusion, advice and support services that should be part of older people's welfare $(§ 71)$.

As one of the most important laws, the Health Reform Act of 1989 included health promotion as an official mandate for the SHI ( $\$ 20$ SGB V). Several major revisions of this law followed. Health promotion was eliminated as a mandatory task in 1996, and reintroduced in 2000 by the SHI-Reform Act (GKVGesundheitsreformgesetz). Since then $\S 20$ SGB V includes the mandate for the SHI to deliver primary prevention services that intend to improve the general state of health and in particular, contribute to the reduction of socially determined health inequalities. In 2007 it was defined by the Act to Strengthen Competition in SHI (Wettbewerbsstärkungsgesetz) that a fixed sum should be spent by health insurance funds on health promotion and primary prevention per year (2,74 Euros per insured person, to be adjusted annually). Interventions funded by the health insurance funds include individual interventions (mainly health courses), setting-oriented interventions in day-care centres, schools or communal settings (e.g. for older people) and workplace health promotion. Apart from that there are several screening and primary prevention programmes that are part of the general range of services of the health insurance funds. The Industrial Safety Act (Arbeitsschutzgesetz) from 1996 is a central legal regulation for workplace health promotion.

Since 2005 there have been several attempts to adopt a law on health promotion and prevention. This was partly driven by the motive to establish prevention, health promotion and public health as the fourth pillar of the healthcare system, next to curative, rehabilitative and long-term care - or at least, to generally improve the coordination of the various actors, to consolidate and clarify responsibilities, and to enhance the effectiveness of prevention and health promotion. While earlier versions of the law tried to incorporate a broader societal perspective, to integrate other policy areas as well, the Act to Strengthen Health Promotion and Preventive Health Care (Preventive Health Care Act/PHCA; Gesetz zur Stärkung der Gesundheitsförderung und Prävention) that entered into force in July 2015 has a strong focus on the social insurance agencies. Prevention is understood as a common task of the statutory social insurance funds, with the participation of the private health and long-term care insurance funds. The main focus is on the SHI, which is funding the reform (and falls within the legislative authority of the federal government).

Primary goals are to establish new structures to strengthen the cooperation and coordination of the different actors, to develop a national prevention strategy, to improve effectiveness and to increase financial resources for health promotion and prevention. For this purpose the statutory health insurance funds are obliged to spend $€ 7$ per insured person per year on health promotion and primary prevention as of 2016 (instead of the hitherto $€ 3$ ). This adds up to approximately $€ 500$ million per year. A minimum amount of $€ 2$ per insured person will have to be spent both on workplace health promotion and on health promotion in specific settings, like childcare facilities, schools, long-term care facilities or other communal settings ( $€ 1,05$ per insured person will have to be spent on the support of health related self-help groups and organisations). These regulations set a very strong focus on setting-oriented health promotion, as this is expected to be more effective - or (rather) more capable of reducing health inequalities - especially compared to health courses (on nutrition, weight reduction, physical activity, stress management, relaxation techniques, addiction prevention) that only address individuals.

\section{Policy, programmes and actions}

A process on national health targets was initiated in 2000 , based on a resolution of the conference of ministers of health (GMK) in 1999. It is carried out by a cooperation network that includes about 160 cooperation partners (gesundheitsziele.de). Eight national health targets have been developed so far:

(1) Diabetes mellitus type 2: lowering the risk of contracting the disease, early recognition and treatment of the disease;

(2) Breast cancer: decreasing the mortality rate, improving quality of life;

(3) Tobacco consumption reduction;

(4) Growing up healthy: life skills, exercise, diet;

(5) Increasing health skills and strengthening patient sovereignty;

(6) Depressive diseases: prevention, early recognition and long-term treatment;

(7) "Healthy ageing" as a national health target was introduced in 2012;

(8) "Reduction of alcohol consumption", added in 2015; For the target "Healthy ageing" (7) a comprehensive report was compiled that includes detailed recommendations in three areas of activity [9]:

- Health promotion and prevention: preserve autonomy; this includes goals concerning social participation, the strengthening of resources, physical activity, a balanced diet and oral health.

- Medical, psychosocial and nursing care: this includes goals concerning supply structures, the cooperation of different health professions and the improvement of the situation of care-taking relatives.

- Special challenges: this concerns the situation of disabled older people, improvement of mental health and dementia, care for multi-morbid patients, the prevention the need for long-term care and good care for persons in need of long-term care.

On the level of the 16 federal states health targets have been defined as well, but these are specific for each federal state and approaches and strategies may differ widely. The majority of them include health targets that are specific to older people. While comprising more or less programmatic recommendations so far, the 
national targets have actually gained importance as they are directly addressed by the PHCA. Consideration of the 8 national health targets and the goals predefined by the national strategy on occupational health and safety is stipulated in the PHCA.

A central structure, newly established by this law, is the Federal Prevention Conference. This is constituted by representatives of the statutory social security funds (health, pensions, accidents, long-term care) and private health insurance funds. Representatives of the federal and the Länder governments, the Federal Employment Agency, the social partners, patient representatives and the Federal Association for Prevention and Health Promotion have a consultative function. The National Prevention Conference has the task of developing a National Prevention Strategy. As one part of this strategy the National Prevention Conference adopted National Basic Recommendations on Health Promotion and Prevention in February 2016, that define common goals, main areas of activity, target groups, and participating organisations and institutions.

Three main guiding goals have been defined:

(1) growing up healthy;

(2) healthy living and working;

(3) being healthy in old age.

Based on these recommendations framework agreements on health promotion are subsequently developed in the 16 Länder. These framework agreements define common areas of activity for the Länder, specify the coordination of services, and clarify the responsibilities and the cooperation with the public health services and other important health promotion providers. This process is still ongoing (Sept. 2016) and will strongly influence the actual implementation of the law.

Further regulations of the PHCA relate, inter alia, to quality assurance, extended functions of the BZgA, recommendations for prevention by physicians and the obligation of the nursing care insurance funds to spend $€ 0,30$ per insured person on health promotion and prevention in long-term care facilities.

Regarding the setting-orientation of the PHCA there is a strong focus to strengthen health promotion interventions especially for children and young persons and in workplace settings. Still "healthy in old age" is one of the defined guiding goals of the National Prevention Strategy, and definite tasks have been defined for nursing care insurance funds, but practice will tell, what the impact for health promotion or preventive interventions for older people will be.

Health promotion for older people is one of the four key fields of action of the network for health equity. This network, Equity in Health (Kooperationsverbund Gesundheitliche Chancengleichheit), was founded in 2003, initiated by the BZgA, with a special focus on supporting health promotion for the socially disadvantaged. It comprises 66 organisations. Next to its networking activities, a main goal is to identify and disseminate Good Practice projects and to strengthen quality development. Parallel to the federal platform, Länder associations for health have established coordi- nation centres for equity in health in the federal states. They are funded by the Länder governments and the health insurance funds.

Regarding the health activity types, the first place within HP4OP in Germany is taken by physical activity. Primary prevention of chronic diseases is also permanently present. Programmes of healthy nutrition, avoiding addiction and fall prevention have been developed. Recently we have been observing many initiatives against mental disorders in older age. Programmes oriented at social inclusion and the social integration of older people in communities are supported nationally and internationally by networks of activists and experts.

\section{Financial position of public health and health promotion generally and for oolder population specifically within the health system}

Current total health expenditure in Germany accounted for $11.1 \%$ of GDP in 2014. The level of resources allocated to health has been steadily increasing (see Table III). During the period 2000-2014, the real current health expenditure per capita (base year 2005) have increased by one third. In the same period, the GDP per capita increased by $17.5 \%$. Approximately $76 \%$ of the health expenditure comes from public sources (largely from social health insurance contributions). Private expenditure includes mostly out-of-pocket payments and private health insurance contributions. A vast majority of health resources $(92 \%)$ is devoted to financing of individual health care services. The expenditure on prevention and public health services accounts for approximately $3 \%$ of total current health expenditure. Since 2007 the share of prevention and public health services on total current health expenditure decreased slowly by 0.5 percentage point.

The specific structure of health promotion funding in Germany is presented in Figure 4, and the key features of the HP4OP funding in particular are summarized in Table IV.

In the health promotion and prevention sectors there are many particular institutions/organisations funding and otherwise supporting health promotion functions generally and those specifically addressed at older people. However the main public payers for those activities are the social health insurance funds and public budgets.

\section{Good practices of health promotion addressed at otder people - selected programmes}

Various good practices in the area of health and activity promotion addressed at older people have been identified in Germany. Some programmes are focused more on activation and the social integration of seniors - not directly on their health. In the last years more practices are healthy ageing oriented. The range of health promotion activities is wide: primary prevention of chronic diseases and falls, avoiding addiction, stimulating physical activity, food control and developing healthy diet, healthy 


\begin{tabular}{|l|c|c|c|c|c|c|c|c|c|}
\hline & 2000 & 2005 & 2007 & 2010 & 2012 & 2013 & 2014 & $\begin{array}{c}\text { Change } \\
2014 \text { to } \\
2000\end{array}$ & $\begin{array}{c}\text { Change } \\
2014 \text { to } \\
2007\end{array}$ \\
\hline $\begin{array}{l}\text { Current health expenditure } \\
\text { per capita. constant price } \\
\text { OECD base year in euro }\end{array}$ & 2669.2 & 2858.9 & 2982.3 & 3289.8 & 3405.5 & 3461.8 & 3548.7 & $+32.95 \%$ & $+18.99 \%$ \\
\hline $\begin{array}{l}\text { GDP per capita. national } \\
\text { currency at GDP price level } \\
\text { 2005 in euro }\end{array}$ & 27165.7 & 27862.7 & 29914.9 & 29869.9 & 31805.0 & 31527.8 & 31923.0 & $+17.51 \%$ & $+6.71 \%$ \\
\hline $\begin{array}{l}\text { Current health expenditure } \\
\text { as \% of GDP }\end{array}$ & 9.8 & 10.3 & 10.0 & 11.0 & 10.8 & 11.0 & 11.1 & +1.3 & +1.1 \\
\hline $\begin{array}{l}\text { Share of general govern- } \\
\text { ment in current health } \\
\text { expenditures }\end{array}$ & 78.6 & 75.6 & 75.4 & 75.7 & 75.6 & 76.3 & 76.6 & -2.3 & +1.2 \\
\hline $\begin{array}{l}\text { Share of private agents in } \\
\text { current health expenditures }\end{array}$ & 21.4 & 24.4 & 24.6 & 24.3 & 24.4 & 23.7 & 23.4 & +2.3 & -1.2 \\
\hline $\begin{array}{l}\text { Individual health care } \\
\text { services and medical goods } \\
\text { share of current expendi- } \\
\text { ture on health) }\end{array}$ & 91.3 & 91 & 91.1 & 91.2 & 91.6 & 91.8 & - & - & - \\
\hline $\begin{array}{l}\text { Collective health care } \\
\text { share of current expenditu- } \\
\text { re on health) }\end{array}$ & 8.7 & 9 & 8.9 & 8.8 & 8.4 & 8.2 & - & - \\
\hline $\begin{array}{l}\text { Prevention and public heal- } \\
\text { th services (share of current } \\
\text { expenditure on health) }\end{array}$ & 3.2 & 3.3 & 3.6 & 3.4 & 3.2 & 3.1 & - & - \\
\hline
\end{tabular}

Table III. Expenditures on health generally and on public health and prevention.

Sources: OECD Health Statistics, http://stats.oecd.org/index.aspx?DataSetCode=HEALTH_STAT; accessed: 27.06.2016.

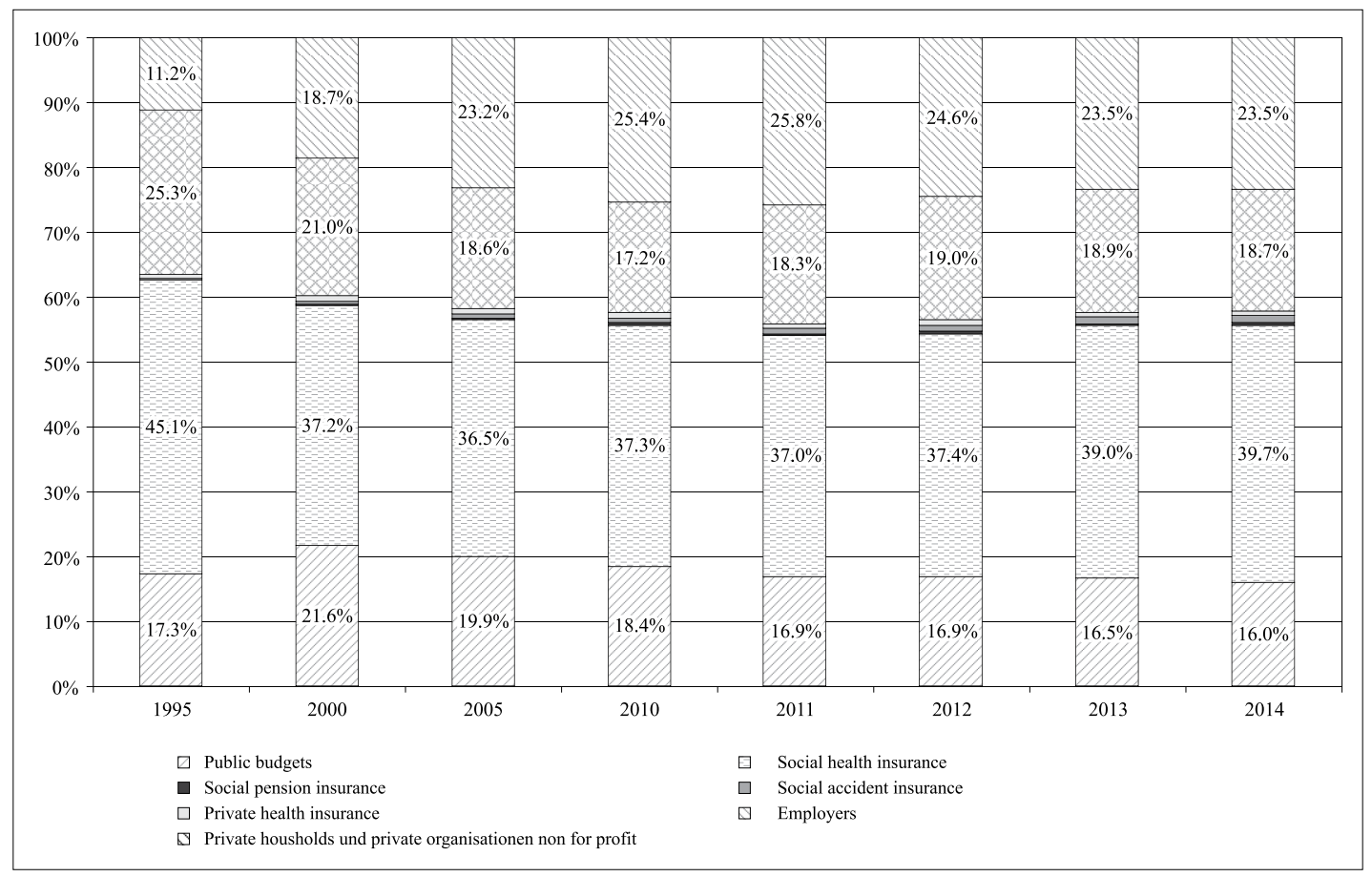

Figure 4. The structure of funding of health promotion.

Source: Own calculation based on Statistisches Bundesamt, Gesundheit. Ausgaben 1995-2014, Wiesbaden 2016, https://www.destatis.de/DE/Publikationen/Thematisch/Gesundheit/Gesundheitsausgaben/AusgabenGesundheitLangeReihePDF 2120712.pdf?_blob=publicationFile; accessed: 10.03.2016 [10]. 


\begin{tabular}{|c|c|c|}
\hline Type of institution & Source of funding & Comments \\
\hline $\begin{array}{l}\text { Governmental institutions: } \\
\text { Federal Ministries of Health and other ministries, Federal Centre } \\
\text { for Health Education } \\
\text { Federal Institute for Occupational Safety and Health } \\
\text { State ministries of health and other ministries, state public health } \\
\text { authorities; state institutes for teacher education and school } \\
\text { development } \\
\text { Local public health authorities; school, kindergarten and day care } \\
\text { administrations }\end{array}$ & $\begin{array}{l}\text { Budgetary funds - general taxation } \\
\text { European Commission - grants ba- } \\
\text { sed on the EU project participation } \\
\text { Local budgets - general and local } \\
\text { taxes }\end{array}$ & \\
\hline $\begin{array}{l}\text { Self-administered institutions: } \\
\text { Statutory health insurance (SHI), statutory pension insurance and } \\
\text { statutory accident insurance Chambers of medical professionals }\end{array}$ & $\begin{array}{l}\text { Insurance funds based on insurance } \\
\text { contributions } \\
\text { Membership fees }\end{array}$ & $\begin{array}{l}\text { Main source of health promotion } \\
\text { funding }\end{array}$ \\
\hline $\begin{array}{l}\text { Non-governmental organisations: } \\
\text { Federal and Länder Associations for Health Promotion and } \\
\text { Prevention; } \\
\text { German Nutrition Society, } \\
\text { German Olympic Sports Confederation } \\
\text { Foundations: e.g. Robert Bosch, Bertelsmann Foundation, Lottery } \\
\text { Foundations, various local foundations } \\
\text { Others NGOs: health centres; local health initiatives; sports clubs }\end{array}$ & $\begin{array}{l}\text { Commitment of SHI } \\
\text { Commitment of Federal and Länder } \\
\text { Ministries } \\
\text { Financial resources from founda- } \\
\text { tions }\end{array}$ & \\
\hline $\begin{array}{l}\text { Private: } \\
\text { Private health insurance } \\
\text { Corporate health promotion activities } \\
\text { [according to the legal code on health and safety at work] } \\
\text { Private broadcasting campaigns }\end{array}$ & $\begin{array}{l}\text { Private insurance premium } \\
\text { Donations and fundraising from } \\
\text { private individuals and corporations }\end{array}$ & $\begin{array}{l}\text { According to the new law (The } \\
\text { Preventive Health Care Act) private } \\
\text { health insurance funds are exempt } \\
\text { from the financing obligation of } \\
\text { preventive activities. } \\
\text { However, voluntary contributions } \\
\text { are suggested and expected. }\end{array}$ \\
\hline
\end{tabular}

Table IV. Funding of health promotion by institutions.

Source: Own comparison.

life style promotion. However, physical activity plays the main role.

Good practices are here presented with short descriptions of the realised programmes; first national healthy life style campaigns, than programs addressed to specific groups of older people, regional projects and last but not least - research projects. In a separate and final section a few European Union programmes are indicated in which the contribution of the German partner is very significant.

\section{A. German active and healthy ageing programmes realized in health and social fields}

\section{- National Action Plan "IN FORM"}

This German national initiative to promote "healthy diets and physical activity" is aimed at bringing about lasting improvements in dietary and exercise habits in Germany by 2020. "IN FORM" is about promoting a healthy lifestyle with a well-balanced diet and sufficient physical activity. To date, almost 100 projects have been supported by the Federal Ministry of Food and Agriculture (BMEL) and the Federal Ministry of Health (BMG) under the IN FORM initiative. A specific internet portal for older people is provided as part of the programme: www.in-form.de/profiportal/service/aeltere/ im-alter-in-form.html.
- Campaign "Fit im Alter - Gesund essen, besser leben" (Fit for old age - eating healthy, living better)

This campaign assists elderly people by offering a comprehensive healthy catering in retirement homes or at home. This campaign is supported by the German Nutrition Society. The final evaluation of the project showed that there were significant changes only for nutrition behaviour, not of physical activity and no change in health related quality of life; http://www.fitimalter-dge.de/.

\section{- Rezept für Bewegung (Prescription for Movement)}

Thanks to a cooperation between the German Olympic Sports Confederation (Deutscher Olympischer Sportbund', DOSB), the German Medical Association (BAK) and the German Society for Sports Medicine in several German regions and cities, physicians prescribe their patients special "green" prescriptions with adjusted sport, PA offer, classes or recommended facilities to use. Annual conferences and forums are organized to promote the green prescription idea. More information: http://www.sportprogesundheit.de/de/sport-und-gesundheit/rezept-fuer-bewegung/

- Health promotion and primary prevention for older people with immigrant backgrounds (20072010)

This project was undertaken by the Institute of Gerontology at the University of Dortmund in Germany 
with the aim of evaluating the effectiveness of health promotion activities for older people with an immigrant background. The project looked at behavioural and environmental determinants of ageing and furthermore, looked into new opportunities for effective health promotion and primary prevention measures for this hard to reach target group. The research project included the evaluation of several targeted prevention measures in the areas of exercise, nutrition and cognitive function among others.

More information is available at: http://www.ffg. tu-dortmund.de/cms/de/Projekte/Lebenslagen_Lebensfor men_und_soziale_Integration/Gesundheitsfoerderung _ und Primaerpraevention/index.html.

\section{- New Ageing in Cities (NAIS)}

NAIS is a volunteer project in partnership with the administration of the city of Bruchsal in Germany, public facilities, churches, charities, trade and industry, associations and clubs. The project has been operational since 2007 and it looks to develop effective local strategies to activate and empower older citizens. Areas of actions include: improving access to the local care system, improving care for older people in socially disadvantaged areas and actions promoting physical activity, nutrition and mental health. More information is available at: http:// www.neues-altern.de/index.html.

\section{- SAĞLIK project}

This project promotes physical activity, nutrition and social participation in urban districts. The SAĞLIK project plans to develop, implement and evaluate community based health promotion interventions for members of the elderly Turkish migrant community in Hamburg with the aims of adapting local health promotion structures and reducing health inequalities. The interventions will focus on improving nutrition, physical activity and social participation. The project takes a multi-stakeholder approach and includes expertise from the public health, health psychology, nutrition science, social sciences and social work professions. More information is available at: http://www.haw-hamburg.de/fakultaeten-und-departments/ls/ls-forschung0/fsp-public-health/aktuelleprojekte/ saglik.html.

\section{- Kölner Seniorennetzwerke (Cologne networks for senior citizens)}

This project is addressed at older people in a suburb with the aim of preventing social exclusion and isolation and to integrate them. It involves local politicians, representatives of senior citizens, local employers and occupational organisations (including kiosk owners, barbers and hairdressers, associations and housing cooperatives as well as pharmacists and medical practitioners. Information is available at: http://seniorennetzwerkekoeln.de.

\section{- Gesund \& aktiv älter werden (Healthy and active ageing)}

This is a Portal of the Bundeszentrale für gesundheitliche Aufklärung (BZgA) focused on health information available at: www.gesund-aktiv-aelter-werden.de.

\section{- Altern in Balance}

This programme is focused on maintaining the somatic and mental health balance of older people, their wellbeing and social integration. The programme has been developed by the $\mathrm{BZgA}$ and is supported by the private health insurance funds (Verband der Privaten Krankenversicherung e.V. (PKV)). The programme initiated a national competition series "Healthy ageing in the municipality - physically active and mobile," which took place for the first time from May 2015 to April 2016. Good practice models and projects in communal settings were honoured for promoting physical activity and the mobility of older people.

For more information see https://wettbewerb-aelterwerden-in-balance.de/wettbewerb.html.

\section{- Equity in Health}

This is a cooperation network established in 2003 on the initiative of the Federal Centre for Health Education (BZgA). The activities of the Network were focused on four key fields: health promotion in districts, for children, the unemployed and the elderly. This cooperation network already has an established structure in the Länder. Noteworthy is its advanced quality development in social status-based health promotion. This initiative is very often indicated in Germany as a good practice; http://www.gesundheitliche-chancengleichheit.de/ english/.

\section{- Diabetes Counselling on Wheels}

This programme concerns early detection and counselling on diabetes for citizens of Turkish origin and the rural population. This pilot programme has been operational since 2003 in North Rhine Westphalia. It is not addressed to a specifically indicated age group but is rather focused on the older population with a Turkish migration background (in rural regions). Its aim is instruction concerning diabetes mellitus (information about this disease, diagnosis at an early stage, referral of newly diagnosed cases to suitable specialist contact persons locally - medical doctors, nurses and others). This project is focused on a target group that is not otherwise reached by preventive measures. The project's evaluation is still underway (2014 to 2018); http://www.chrodis.eu/wp-content/ uploads/2016/03/160307DiabetesCounsellingOnWhee 1s_DraftProgramme_5.pdf.

\section{- Prevention of type II diabetes}

The TULIP study (Tübingen lifestyle, Programme of Intervention, University Hospital of the Medical Faculty Tübingen) is addressed to the population over 50; people with an increased risk profile for type II diabetes mellitus whose parents suffer from diabetes, women who have developed diabetes during pregnancy, people with reduced glucose tolerance, older people who are overweight with a BMI of more than 27. Its aims are the identification of important predictive parameters (preventive strategies in terms of lifestyle change), motivation for a healthier lifestyle (more physical activity and a healthier diet), prevention of diseases of civilisation (type II diabetes, vascular calcification and myocardial infarction). The project in- 
volves medical practitioners, nutrition specialists, sports scientists, sports physicians and nurses, as described by [11].

\section{- BMBF Förderschwerpunkt Präventionsforschung}

(Funding Priority Prevention Research)

The Federal Ministry of Education and Research (BMBF) funded a priority research programme on prevention research from 2004 to 2013. This programme focussed on older people from 2007 to 2010 and funded 14 research projects on health promotion and prevention for older people. In addition a coordination project was initiated in 2009 to establish structures that ensure the application and sustainable use of research results in practice ["Kooperation für nachhaltige Präventionsforschung"] (Cooperation for sustainable research), http://www.knpforschung.de/. The research projects on interventions for older people are presented in a brochure: Ergebnisse der Präventionsforschung nutzen - Präventionsprojekte für ältere Menschen, available at: http://www.bzga.de/infomaterialien/einzelpublikationen/?idx=2096.

\section{- AEQUIPA}

This is a research network focused on prevention in North-West Germany, coordinated by the LeibnizInstitute - BIPS. The AEQUIPA Network is funded by the Federal Ministry of Education and Research. Three aims are defined: (1) to assess the Community Readiness (CR) for older adults' physical activity in selected municipalities in the Metropolitan Region Bremen Oldenburg in the Northwest, (2) to investigate the efficacy and costeffectiveness of capacity building strategies to increase CR to engage vulnerable older adults (e.g., low SES, obese) in physical activity interventions, (3) to examine reasons for (non-) participation in existing physical activity interventions among older adults; www.aequipa.de/.

\section{B. Participation in European Health- and Senior tar- get Projects}

\section{- EuroHealthNet}

This is the network of a not for profit partnership of organisations, agencies and statutory bodies with the aim of creating successful healthcare communication programmes to contribute to a healthier Europe by promoting health and health equity between and within European countries. It has been operational since 1996. The German partner is The Federal Centre for Health Education [BZgA]; http://www.eurohealthnet.

\section{- AGE platform Europe}

This Platform is a European network of organisations of and for people aged 50+. AGE was set up in January 2001 to represent the needs of older people to European institutions with a single voice, as well as to strengthen the cooperation between older people's organisations across the EU. The German partners are A Soul for Europe - Berlin, Citizens of Europe - Berlin, Egality Berlin, The European Institute for Public Participation (EIPP) - Bremen and among others N-OST - the network for reporting on Eastern Europe; http://www.ageplatform.eu.

\section{- EPIC - Elderly Network on Ageing and Health}

This is a project founded in 2004 by the European Commission - DG Health and Food Safety, which was realised in the years 2005-2007. The aim was to set up a health information and surveillance programme for reporting issues relevant to ageing and health, by establishing a central databank of standardised data including baseline information on socio-demographic, dietary, lifestyle, somatometric characteristics and self-reported morbidity, as well as follow up data on any of the above mentioned parameters and cause specific mortality of elderly Europeans. German Partners - Deutsches Krebsforschungszentrum (DKFZ) and Deutsches Institut für Ernährungsforschung Potsdam-Rehbrücke (DIEF); http://ec.europa.eu/health/ph_projects/2004/action1/docs /2004_1_06_inter_en.pdf.

\section{- From Isolation to Inclusion (The i2i-project)}

This project was a part of the Second Trans-national Exchange Programme (2005-2007) and was implemented in Austria, the Czech Republic, Germany, Italy, Lithuania and the UK, focused on improving the social participation of older people at risk of isolation or poverty, those with disabilities or chronic diseases, or from ethnic minorities. In each of the countries in which the project was carried out, co-operation took place between a regional or local public authority and an external consultant. The aim was to capitalise on political momentum and expert knowledge, so as to facilitate and encourage social and political changes aimed at improving the conditions of the vulnerable target groups.

More information is available at: http://www.i2iproject.net/.

\section{- Vintage - Good health into older age}

This project was funded by the European Commission under the Second Programme of Community Action in the Field of Health 2008-2013. The objective was to build capacity at the European, national and local levels by providing the evidence base and collecting best practices to prevent the harmful use of alcohol amongst older people, including the transition from work to retirement, and to invest in older people's health and well-being. The project was realised from the years of 2009-2011. The German collaborating partner was DHS - Deutsche Haupstelle für Suchtfragen - Hamm; http://www.epicentro.iss.it/vintage/.

\section{- Health Pro Elderly - Evidence Based Guidelines on Health Promotion for Elderly: social determi- nants, inequality and sustainability}

This project was realised within the Public Health Programme of the European Commission, (2008-2013). The overall aim was to support health promotion for older people by developing evidence-based guidelines and recommendations for action at the European, national and local levels. Determinants that influence the health situation of the elderly would be highlighted, enabling differentiation between the different target groups and their needs, taking into consideration the inequalities that the target groups are confronted with. The German 
associated partner was Forschungsgesellschaft für Gerontologie e.V.; http://www.healthproelderly.com/.

\section{- PASEO - Successful Alliance Building for Physical Activity Promotion among older People}

This project, co-funded by the DG Health and Consumers from 2009-2011, covered 15 EU Member States - Germany included - Bavarian Ministry of Public Health and University of Erlangen Nurnberg. It was addressed to older people in general with the aim of promoting physical activity among sedentary older people by strengthening the local, regional and national capacities to facilitate two key areas: the creation of intersectoral capacities (cooperation of organisations across multiple policy sectors - i.e. health, social care, sport) and enhancing institutional efforts to promote physical activity among older people (also building intra-organisational capacities - i.e. personnel, resources, co-operation within organisations). Information is available at: http://ec.europa.eu/chafea/documents/news/Workshop_ on_Transfer_of_Knowledge_.

\section{- JA-CHRODIS - Addressing Chronic Diseases \& Healthy Ageing through Life}

This project was funded by the European Commission under the Second Programme 2008-2013 of Community Action in the field of health. The German partner Bundeszentrale für gesundheitliche Aufklärung (BZgA) [The Federal Centre for Health Education] was responsible for facilitating the exchange, upscaling, and transfer of good practices in health promotion and primary prevention of chronic diseases, in particular, type 2 diabetes and cardiovascular diseases, between EU countries and regions - Work Package 5. The final report of the work presents, in detail, criteria used to select prevention activities indicated as good practice and then describes selected practices in 14 European countries. One of the key deliverables is the 'Platform for Knowledge Exchange,' which will include both an online help-desk for policy makers and an information portal providing an up-to-date repository of best practices and the best knowledge on chronic care. Information is available at: www.chrodis.eu.

\section{Conclusions}

Health promotion in Germany comprises a wide field of activities and involves a wide range of actors. There are many strong networking activities, a high level of exchange of experience and expertise and many model projects. It is thus a highly developed and differentiated field. And there is an especially wide field of (demanddriven) open offers people can attend, such as individual health classes concerning physical activity, nutrition or relaxation offered by e.g. adult or senior education centres or sports clubs.

Despite these definite strengths, there is little longterm and sustainable infrastructure with secured funding for setting-oriented interventions that try to reach specific target groups and especially the socially disadvantaged, who do not attend individual interventions. Services and activities differ widely from region to region. Health promotion, especially for older people, often takes place within the scope of singular projects or initiatives.

There are no comprehensive and standardised services for health promotion and primary prevention for older people [12]. The Preventive Health Care Act is a new attempt to overcome the problem of insufficient coordination among different actors on different policy levels. But there is still criticism that the law does not define health promotion and primary prevention as a task for society as a whole, as "Health in All Policies," but focuses mainly on the responsibility of the SHI. A main point of contention is that the activities defined in the law are still to be financed by the SHI and not by taxes. Private health insurance funds, which cover, for example, public officials, are exempt from this financing obligation. Furthermore, based on past experiences, there are doubts as to whether the competitive health insurance funds are appropriate agents to realise effective health promotion policies especially the necessary setting-oriented interventions for the socially disadvantaged. In a competitive health market, health insurance funds are mainly interested in promoting individual health promotion interventions for healthy and health-conscious people, as these are the most profitable clients [13].

The law provides regulations to strengthen cooperation between insurance funds, but it remains to be seen, whether sustainable structures will be developed in the next years. In general the Preventive Health Care Act is regarded as a step in the right direction, by strengthening health and setting-oriented health promotion in particular.

\section{Notes}

${ }^{1}$ Eurostat data: http://ec.europa.eu/eurostat/data/database; accessed: 30.03 .2016 .

${ }^{2}$ The ratio between the number of persons aged 65 and over (age when they are generally economically inactive) and the number of persons aged between 15 and 64 . The value is expressed per 100 persons of working age (15-64) (Eurostat).

${ }^{3}$ European health for all database (HFA-DB) WHO Regional Office for Europe, http://data.euro.who.int/hfadb/; accessed: 02.04.2016.

${ }^{4}$ Eurostat data: http://ec.europa.eu/eurostat/data/database; accessed: 07.04.2016.

\section{References}

1. Busse R., Blümel M., Germany: health system review, "Health Systems in Transition" 2014; 16 (2): 1-331, http:// www.euro.who.int/_data/assets/pdf_file/0008/255932/ HiT-Germany.pdf?ua=1; accessed: 17.03.2016.

2. Raphael D., The political economy of health promotion: part 1, national commitments to provision of the prerequisites of health, "Health Promotion International" 2011; 28 (1): 91-111.

3. Robert Koch Institut, Gesundheitsberichterstattung des Bundes gemeinsam getragen von RKI und Destatis, Gesundheit in Deutschland, Berlin 2015.

4. Kaba-Schönstein L., Gesundheitsförderung $V$ : Die Entwicklung in Deutschland ab Mitte der 1980er Jahre, 
Leitbegriffe der Gesundheitsförderung, Bundeszentrale für gesundheitliche Aufklärung, letzte Aktualisierung am 15.02.2011, http://www.leitbegriffe.bzga.de/alphabetisches-verzeichnis/gesundheitsfoerderung-v-die-entwicklung-in-deutschland-ab-mitte-der-1980er-jahre/; accessed: 30.08.2016.

5. Sitko S., Kowalska-Bobko I., Mokrzycka A., Zabdyr-Jamróz M., Domagała A., Magnavita N., Poscia A., Rogala M., Szetela A., Golinowska S., Institutional analysis of health promotion for older people in Europe, "BMC Health Services Research" 2016; 16 (Suppl. 5): 327.

6. Blümel S., Akteure, Angebote und Strukturen in: Bundeszentrale für gesundheitliche Aufklärung (eds), Leitbegriffe der Gesundheitsförderung und Prävention, Verlag für Gesundheitsförderung, Werbach-Gamburg 2011.

7. Kunkel T., Good practices in the field of health promotion and primary prevention, Germany Country Review, JA-Chrodis Project, Federal Centre for Health Education (BZgA), Cologne 2015, http://www.chrodis.eu/wp-content/uploads/2015/02/Germany-country-review; accessed: 14.09.2016.

8. Walter U., Schwartz W., Prävention: Institutionen und Strukturen, in: Public Health Buch. Gesundheit und Gesundheitswesen, F.M. Schwartz (red.), Urban \& Fischer, München 2003, 2012.

9. Kooperationsverbund gesundheitsziele.de, Nationales Gesundheitsziel “Gesund älter werden”, Bundesministerium für Gesundheit (red.), Berlin 2012, http://gesundheitsziele. $\mathrm{de} / / \mathrm{cms} /$ medium $/ 814 /$ Gesund_aelter_werden_020512.pdf; accessed: 30.08.2016.

10. Statistisches Bundesamt, Gesundheit, Ausgaben, Wiesbaden 2015, https://www.destatis.de/DE/Publikationen/Thematisch/Gesundheit/Gesundheitsausgaben/AusgabenGesund heitLangeReihePDF_2120712.pdf?_blob=publicationFile; accessed: 10.03.2016.

11. Häring H.-U., Fritsche A., Prävention des Typ-2-Diabetes. TULIP-Studie - Tübinger Lebensstil Interventionsprogramm, in: Stierle M., Stierle G., Roth B., Bertelsmannstiftung (eds), Deutscher Präventionspreis 2005. Gesund in der zweiten Lebenshälfte (50plus). Die Preisträger und Nominierten, Druckerei festge, Oelde 2005.

12. Kuhlmann A., Koch K., Gesundheitsförderung und Prävention für ältere Menschen im Setting Kommune, Institut für Gerontologie an der Technischen Universität Dortmund, Dortmund 2009, http://www.kas.de/wf/doc/13261-14421-30.pdf; accessed:14.04.2016

13. Gerlinger T., Präventionsgesetz, Leitbegriffe der Gesundheitsförderung, Bundeszentrale für gesundheitliche Aufklärung, letzte Aktualisierung am 12.07.2016, http:// www.bzga.de/leitbegriffe/?id=angebote $\& \mathrm{idx}=296$; accessed: 20.10.2016.

\section{Legal and policy documents:}

1. BMEL (Federal Ministry of Food) and BMG (Federal Ministry of Health), Mehr Bewegung im Alter - Aktives Leben im Alter fördern, 2014, http://www.bewegung-foerdern. de/fileadmin/user_upload/MAIN-bilder/ZfB/Berlin/MehrBewegung-im-Alltag.pdf; accessed: 14.09.2016.

2. Bundeszentrale für gesundheitliche Aufklärung (BZgA), Good Practice in the Field of Health Promotion and Primary Prevention, Joint Action on Chronic Diseases and Promoting Healthy Ageing Across the Life Cycle, EU project JA-CHRODIS, 2013.

3. Deutsche Bundesregierung, Deutschlands Zukunft gestalten. Koalitionsvertrag zwischen CDU, CSU und SPD-18. Legislaturperiode, 2013, http:/www.bundesregierung.de/ Content/DE/_Anlagen/2013/2013-12-17-koalitionsvertrag. pdf; accessed: 25.08.2016.

4. EuroHealthNet (Ingrid Stegeman, Terese Otte-Trojel, Caroline Costongs and John Considine), Healthy and active ageing. A compendium of programmes, good practices and other resources for promoting and sustaining the well-being of "younger" older people, with a specific reference to socially deprived and migrant groups in Europe. Bundeszentrale für gesundheitliche Aufklärung (BZgA) incorporating work under taken by Thomas Altgeld, Landesvereinigung für Gesundheit und Akademie für Sozialmedizin Niedersachsen e. V. and Judith Sinclair-Cohen, 2012.

5. Gesetz zur Stärkung der Gesundheitsförderung und der Prävention (Präventionsgesetz - PrävG), vom 17. Juli 2015, Bundesgesetzblatt Jahrgang 2015, Teil I Nr. 31, Bonn 24.07.2015, http://www.bgbl.de/xaver/bgbl/start. xav?startbk=Bundesanzeiger_.

BGB1\&jumpTo=bgbl115s1368.pdf; accessed: 30.08.2016.

6. Gesetz über die Durchführung von Maßnahmen des Arbeitsschutzes zur Verbesserung der Sicherheit und des Gesundheitsschutzes der Beschäftigten bei der Arbeit (Arbeitsschutzgesetz - ArbSchG). 07.08.1996, last amended 31.08.2015, https://www.gesetze-im-internet.de/bundesrecht/arbschg/gesamt.pdf; accessed: 30.08.2016.

7. GKV-Spitzenverband/Medizinischer Dienst des Spitzenverbandes, Präventionsbericht 2015. Leistungen der gesetzlichen Krankenversicherung: Primärprävention und betriebliche Gesundheitsförderung Berichtsjahr 2014. GKV Spitzenverband, Medizinischer Dienst des Spitzenverbandes, Verbände der Krankenkassen auf Bundesebene, Berlin 2015.

8. GKV-Spitzenverband, Leitfaden Prävention. Handlungsfelder und Kriterien des GKV-Spitzenverbandes zur Umsetzung der $\$ \S 20$ und 20a SGBV vom 21. Juni 2000 in der Fassung vom 10. Dezember 2014, Berlin 2014.

9. GKV, Prävention und Gesundheitsförderung weiterentwikkeln. Positionspapier des GKV-Spitzenverbandes beschlossen vom Verwaltungsrat am 27. Juni 2013, https://www. gkv-spitzenverband.de/media/dokumente/krankenversicherung_1/praevention_selbsthilfe_beratung/praevention/2013-07-11_Positionspapier_Praevention_und_Gesundheit.pdf; accessed: 25.08.2016. 